Virginia Commonwealth University VCU Scholars Compass

\title{
The anti-sepsis activity of the components of Huanglian Jiedu Decoction with high lipid A- binding affinity
}

Guirong Chen

Liaoning University of Traditional Chinese Medicine

Yubin $\mathrm{Xu}$

Shenyang Agricultural University

Jing Jing

Liaoning University of Traditional Chinese Medicine

See next page for additional authors

Follow this and additional works at: http://scholarscompass.vcu.edu/medc_pubs

Part of the Pharmacy and Pharmaceutical Sciences Commons

(c) 2017 Elsevier B.V. All rights reserved.

\section{Downloaded from}

http://scholarscompass.vcu.edu/medc_pubs/26

This Article is brought to you for free and open access by the Dept. of Medicinal Chemistry at VCU Scholars Compass. It has been accepted for inclusion in Medicinal Chemistry Publications by an authorized administrator of VCU Scholars Compass. For more information, please contact libcompass@vcu.edu. 
Authors

Guirong Chen, Yubin Xu, Jing Jing, Brianna Mackie, Xinchuan Zheng, Xu Zhang, Jing Wang, and Xuetao Li 


\title{
The anti-sepsis activity of the components of Huanglian Jiedu Decoction with high lipid A-binding affinity
}

\author{
Guirong Chen ${ }^{\mathrm{a}}$, Yubin Xu ${ }^{\mathrm{b}, *}$, Jing Jing ${ }^{\mathrm{a}}$, Brianna Mackie ${ }^{\mathrm{c}}$, Xinchuan Zheng ${ }^{\mathrm{d}}$, Xu Zhang ${ }^{\mathrm{a}}$, \\ Jing Wang ${ }^{\mathrm{a}}$, Xuetao $\mathrm{Li}^{\mathrm{a}, *}$ \\ a College of Pharmacy, Liaoning University of Traditional Chinese Medicine, 77 Life One Road, DD port, Dalian 116600, China \\ b Key Laboratory of Biological Invasions and Global Changes, College of Biological Science and Technology, Shenyang Agricultural University, Shenyang 110161, China \\ c Department of Medicinal Chemistry, Virginia Commonwealth University, 23219, USA \\ d Medical Research Center, Southwest Hospital, Third Military Medical University, Chongqing 400038, China
}

\section{A R T I C L E I N F O}

\section{Article history:}

Received 31 October 2016

Received in revised form 9 February 2017

Accepted 27 February 2017

Available online 6 March 2017

\section{Keywords:}

Lipid A

Palmatine

LPS

Huanglian Jiedu Decoction

Anti-sepsis activity

\begin{abstract}
A B S T R A C T
Huanglian Jiedu Decoction (HJD), one of the classic recipes for relieving toxicity and fever, is a common method for treating sepsis in China. However, the effective components of HJD have not yet been identified. This experiment was carried out to elucidate the effective components of HJD against sepsis. Thus, seven fractions from HJD were tested using a biosensor to test their affinity for lipid A. The components obtained that had high lipid Abinding fractions were further separated, and their affinities to lipid A were assessed with the aid of a biosensor. The levels of LPS in the blood were measured, and pathology experiments were conducted. The LPS levels and mRNA expression analysis of TNF- $\alpha$ and IL- 6 of the cell supernatant and animal tissue were evaluated to investigate the molecular mechanisms. Palmatine showed the highest affinity to lipid A and was evaluated by in vitro and in vivo experiments. The results of the in vitro and in vivo experiments indicated that the levels of LPS, TNF- $\alpha$ and IL- 6 of the palmatine group were significantly lower than those of the sepsis model group $(p<0.01)$. The group treated with palmatine showed strong neutralizing LPS activity in vivo. The palmatine group exhibited stronger protective activity on vital organs compared to the LPS-induced animal model. This verifies that HJD is a viable treatment option for sepsis given that there are multiple components in HJD that neutralize LPS, decrease the release of IL- 6 and TNF- $\alpha$ induced by LPS, and protect vital organs.
\end{abstract}

(c) 2017 Elsevier B.V. All rights reserved.

\section{Introduction}

Lipopolysaccharide (LPS) molecules are found on the outer membrane of many ram-negative bacteria and cover up to $75 \%$ of the cell surface [1]. Studies have shown that LPS is an indispensable molecule for the growth and survival of most Gram-negative bacteria [2,3]. Once toxic LPS is released, LPS plays a key role in Gram-negative infections in humans [4,5]. LPS is composed of three distinct domains that are covalently bound to each other. These domains are the amphipathic lipid A unit, core polysaccharides, and 0-antigen [6-8]. Lipid A's primary function is protection and defence, which can stimulate the innate immune system $[9,10]$. Most of the immune stimulating abilities of LPS can be attributed to lipid A. Lipid A is necessary to activate the Tolllike receptor 4 (TLR4) signalling pathway by binding to the TLR4 co-receptor protein myeloid differentiation factor 2 (MD-2) [11-13]. TLR4 does not directly bind with LPS and requires a co-receptor, MD-2. MD-

\footnotetext{
* Corresponding authors.

E-mail address: Xuyubin1988@126.com (Y.Xu).
}

2 interacts with the extracellular domain of TLR4 and is critical for LPS discrimination due to the unique hydrophobic cavity of MD-2, which can directly bind lipid A [6]. Lipid A binds to the TLR4/MD-2 complex and results in two different signalling transduction pathways that generate the release of pro-inflammatory-cytokines and lead to a significant enhancement of the host to fight infection [14-16]. Nevertheless, the binding of lipid A and the TLR4/MD-2 receptor complex may cause an uncontrolled and considerable immune response, which can result in life-threatening syndromes, such as sepsis. Sepsis is a common inflammation syndrome induced by infection. Severe sepsis has life threatening complications and is a common cause of death in intensive care units. Studies show that LPS is the main promoter for mediating sepsis [17-20]. Therefore, LPS should be an ideal therapeutic target in the field of critical care and emergency medicine.

LPS is the major mediator of sepsis, and research indicates that the molecules that bind to and neutralize LPS could have potential anti-septic action $[21,22]$. Lipid A, the active centre of LPS, has been identified as the toxic component of LPS. Therefore, lipid A was used as the target for screening anti-sepsis agents [23,24]. Polymyxin B (PMB), a well-known 
<smiles>COc1cc2c(cc1OC)-c1cc3ccc(OC)c(OC)c3c[n+]1CC2</smiles>

Palmatine<smiles>O=c1cc(-c2ccc(O)c(O)c2)oc2cc(O)cc(O)c12</smiles>

Luteolin<smiles>COc1cc2c(cc1O)CC[n+]1cc3c(OC)c(OC)ccc3cc1-2</smiles>

Jatrorrhizine<smiles>O=c1cc(-c2ccccc2)oc2cc(O)c(O)c(O)c12</smiles>

Wogonin

Fig. 1. Structures of the compounds. The structures of these compounds were characterized by ${ }^{1} \mathrm{H}$ NMR and ${ }^{13} \mathrm{C}$ NMR spectra.

compound that neutralizes LPS, binds to the negative substituents of lipid A. Therefore, lipid A was coated with blank and the affinity of varying concentrations of PMB was evaluated using a biosensor. The $K_{\mathrm{d}}$ value, reported in the literature as $K_{\mathrm{d}}=10-100 \mathrm{nM}$, was calculated by the FASTit software [25]. The biosensor system showed the advantages of convenience, speed and reliability when screening the lipid A ligand.

Huanglian Jiedu Decoction (HJD) is an important multi-herb remedy in traditional Chinese medicine (TCM) that is composed of four herbs: Coptis chinensis Franch., Scutellaria baicalensis Georgi, Phellodendron amurense Rupr. and Gardenia jasminoides J.Ellis at a ratio of 3:2:2:3. Recently, an increasing amount of evidence has revealed the pharmacological effects of this formula on sepsis, inflammation, gastrointestinal disorders, diabetes, vasodilation, acute liver injury, Alzheimer disease, and cardiovascular diseases [26-29]. HJD has been used for treating sepsis in China, but the effective components of HJD have not yet been elucidated. Therefore, it is necessary to elucidate the effective components of HJD through LPS-induced animal models for the eventual treatment of sepsis. In this experiment, HJD has been proposed to bind to lipid A, the bioactive centre of LPS, to treat sepsis. A biosensor method was used to screen components from HJD with high affinity to lipid A. The activity assessment was carried out in vitro and in vivo. Sepsis animal models were induced by endotoxin (LPS) to elucidate the effective components of HJD.

\section{Materials and methods}

\subsection{Reagents}

Lipid A (from Samonella Re595), LPS (from Escherichia coli 0555:B5), and Polymyxin B sulphate salt (PMB) were purchased from Sigma Chemicals (St Louis, MO, USA). The rat TNF- $\alpha$ and IL-6 ELISA kits were from Diaclone Research (Besançon, France). Quantitative chromogenic tachypleus amebocyte lysate was purchased from Xiamen tal Co., Ltd. (Fujian, China). Silica gel was purchased from QingDao Marine Chemical Factory (QingDao, China). Macroporous resin AB-8 was from Cangzhou Sage. Endotoxin detection was from Chinese Horseshoe Crab Reagent Manufactory Chemical Co. Ltd. (Hebei, China).

\subsection{Traditional Chinese herbs}

The four traditional Chinese herbs, Coptis chinensis Franch., Scutellaria baicalensis Georgi., Cortex Phellodendri. and Gardeniae Fructus. were purchased from Liaoning Province and identified in the College of Pharmacy, Liaoning University of Traditional Chinese Medicine.

\subsection{Animals}

Balb/c mice (4-6 weeks old) were obtained from the Experimental Animal Center of Liaoning Benxi Changsheng Biotechnology Co. Ltd., (Liaoning, China). Equal numbers of male and female mice were used. The weight of the mice in the experiments was $20 \pm 2 \mathrm{~g}$. All of the reports were guided by the Animal Center of Liaoning University of Traditional Chinese Medicine, and the animal performance protocol was approved by the ethics committee of the institution.

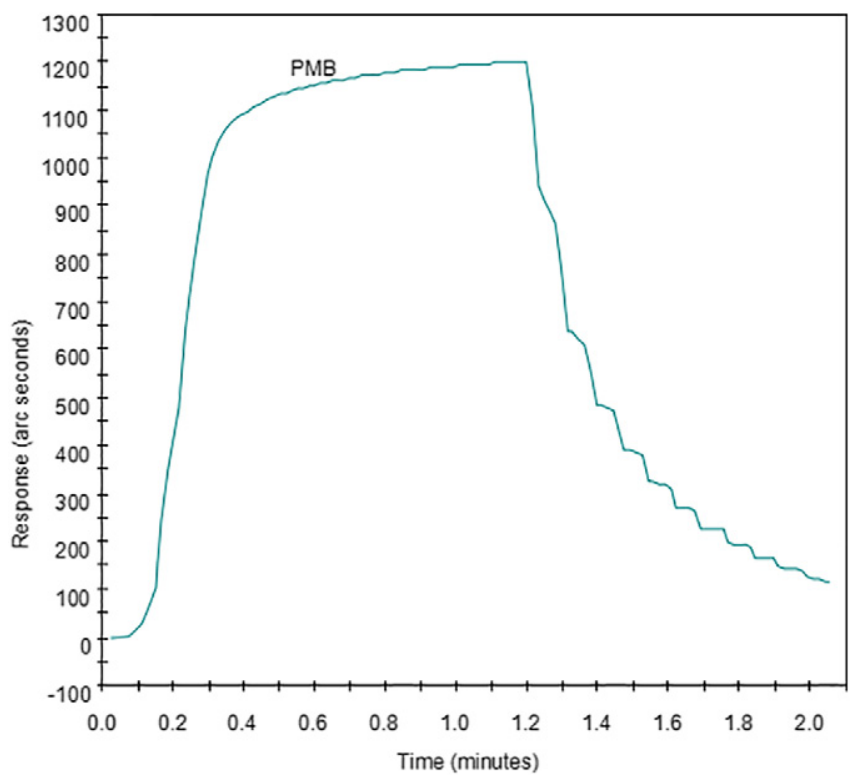

Fig. 2. Affinity of PMB for lipid A. To define the specificity of PMB for lipid A, Lipid A was immobilized on the surface of a hydrophobic cuvette (Thermo Labsystem, USA) using the manufacturer's instructions, different concentrations of PMB were added to the immobilized lipid A the $K_{\mathrm{d}}$ value was measured by FASTfit. 


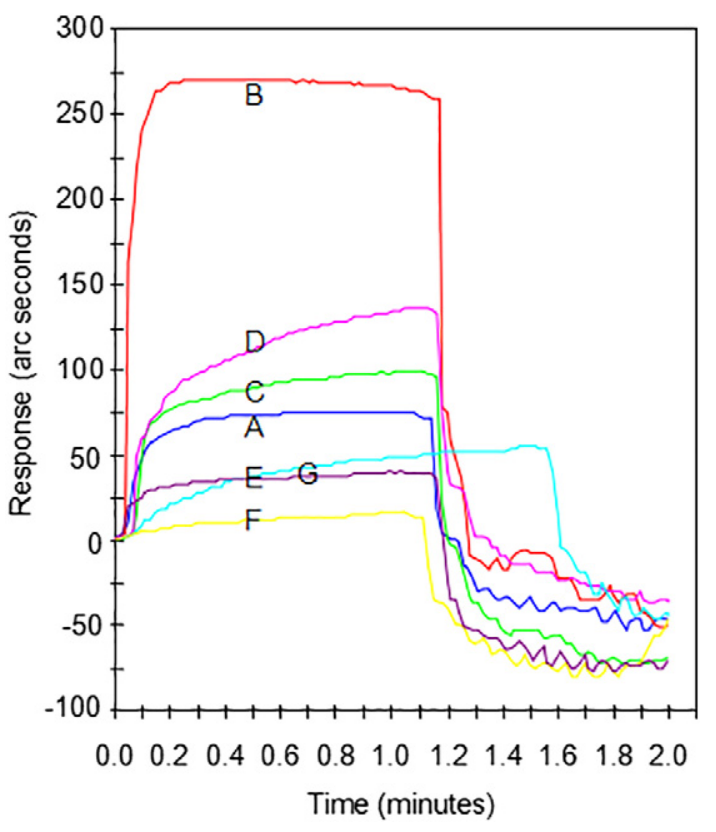

Fig. 3. The assay for the affinity of compounds for lipid A. To define the specificity of these compounds for lipid A, $5 \mu \mathrm{L}$ for each component was added into the cuvette, and the data was collected and analysed with the FASTplot software. A: geniposide; B: palmatine; C: baicalin; D: berberine; E: luteolin; F: wogonin; G: jatrorrhizine.

\subsection{Compounds prepared from $H J D$}

The $1800 \mathrm{~g}$ of the mixed herbs (Coptis chinensis Franch., Scutellaria baicalensis Georgi., Cortex Phellodendri. and Gardeniae Fructus = $3: 2: 2: 3)$ were measured in a 3:2:3:3 ratio, respectively. Water was used as the solvent to extract soluble components $(2 \times 1 \mathrm{~h})$. The extract was obtained followed by hot filtration. When the extract cooled to room temperature, precipitation and the supernatant were formed. The precipitation and supernatant were obtained with centrifugal separation. The supernatant was concentrated under vacuum to $0.25 \mathrm{~g} / \mathrm{mL}$ and then treated by macroporous resin column chromatography with distilled water and 50\% ethanol as the mobile phase. Fractions 1 and 2 were obtained by collecting the eluent separately. The precipitation was purified by polyamide column chromatography with distilled water and 50\% ethanol as the mobile phase. Subsequently, fractions 3 and 4 were obtained through the same elution mentioned above.

\subsection{Compounds prepared from higher affinity fractions}

Fractions 3-4 were treated with silica gel column chromatography, and dichloromethane-methanol was used as the eluent for further separation and purification. Compounds $1-6$ were purified, and their structures were characterized by ${ }^{1} \mathrm{H}$ NMR and ${ }^{13} \mathrm{C}$ NMR. Fraction 2 was
Table 1

The real-time PCR analysis of IL-6 (B) and TNF- $\alpha$ mRNA expression in cells.

\begin{tabular}{lllll}
\hline Group & & $\begin{array}{l}\text { IL-6/ } \beta \text {-arctin } \\
\text { mRNA }\end{array}$ & $\begin{array}{l}\text { TNF- } \alpha / \beta \text {-arctin } \\
\text { mRNA }\end{array}$ & $\begin{array}{l}\text { TLR4/ } \beta \text {-arctin } \\
\text { mRNA }\end{array}$ \\
\hline Model & & $231.16 \pm 1.34$ & $2.70 \pm 0.16$ & $0.49 \pm 0.02$ \\
Palmatine & $16 \mu \mathrm{g} / \mathrm{mL}$ & $221.32 \pm 1.67^{* *}$ & $2.39 \pm 0.22^{* *}$ & $0.26 \pm 0.03^{* *}$ \\
& $64 \mu \mathrm{g} / \mathrm{mL}$ & $197.02 \pm 2.10^{* *}$ & $1.83 \pm 0.19^{* *}$ & $0.22 \pm 0.02^{* *}$ \\
& $128 \mu \mathrm{g} / \mathrm{mL}$ & $162.44 \pm 1.51^{* *}$ & $1.78 \pm 0.15^{* *}$ & $0.14 \pm 0.04^{* *}$ \\
\hline
\end{tabular}

Compared with the model group, ${ }^{*} p<0.05,{ }^{* *} p<0.01$. It was conducted 1 h after treatment as described previously. Model group was recognized as a control group. The expression of TNF- $\alpha$ and IL- 6 mRNA was determined and the data were analysed by one-way analysis of variance (ANOVA) followed by Dunnett's method.

purified by silica gel column chromatography and eluted with dichloromethane-methanol $(25: 1,10: 1,5: 1$ and $2: 1)$. The fraction of dichloromethane-methanol, 10:1, was purified repeatedly by silica gel column chromatography, and compound 7 was obtained and the structure characterized by the ${ }^{1} \mathrm{H}$ NMR and ${ }^{13} \mathrm{C}$ NMR spectrum.

\subsection{Affinity assessment}

The affinity assessment was performed according to method reported in the literature [30,31]. Lipid A was immobilized on the surface of a hydrophobic cuvette (Thermo Labsystem, USA) using the manufacturer's instructions. The hydrophobic cuvette was pretreated with 2-propanol and PBS/AE. Ten microliters of 50\% 2-propanol and $10 \mu \mathrm{L}$ of lipid A were mixed together in the cuvette. Next, the cuvette was washed with $60 \mu \mathrm{L} \mathrm{PBS} / \mathrm{AE}$, and the data were collected. Then, the cuvette was alternately washed with $\mathrm{PBS} / \mathrm{AE}$ and $\mathrm{NaOH}$ seven times, and the data were collected after the seventh wash of PBS/AE. The sensor surface was covered with lipid A for 251 arc sec. Different concentrations of PMB were added after the lipid A was immobilized on the surface of the hydrophobic cuvette, and a binding curve was generated and $K_{\mathrm{d}}$ values were evaluated with affinity Sensors IAsys. Additional analyses were performed with the help of the FASTplot and FASTfit software packages (Thermo Labsystem, USA). The experiment was carried out using an Affinity Sensors IAsys Plus system for detecting the abovementioned components that bind to lipid A. The compounds prepared from HJD were screened against lipid A in search of the compounds with high binding activity. The details of the experiment were repeated as before. Five microliters of each component was added to the cuvette, and the data were collected and analysed with the FASTplot software.

\subsection{Cell culture and treatment}

Murine macrophage-like cells (RAW264.7) were purchased from the Type Culture Collection of the Chinese Academy of Sciences, Shanghai, China. The cells were cultured in Dulbecco's modified Eagle's medium supplemented with $100 \mathrm{mg} / \mathrm{L}$ of penicillin/streptomycin and $10 \%$ heat-inactivated foetal bovine serum, in a humidified atmosphere of
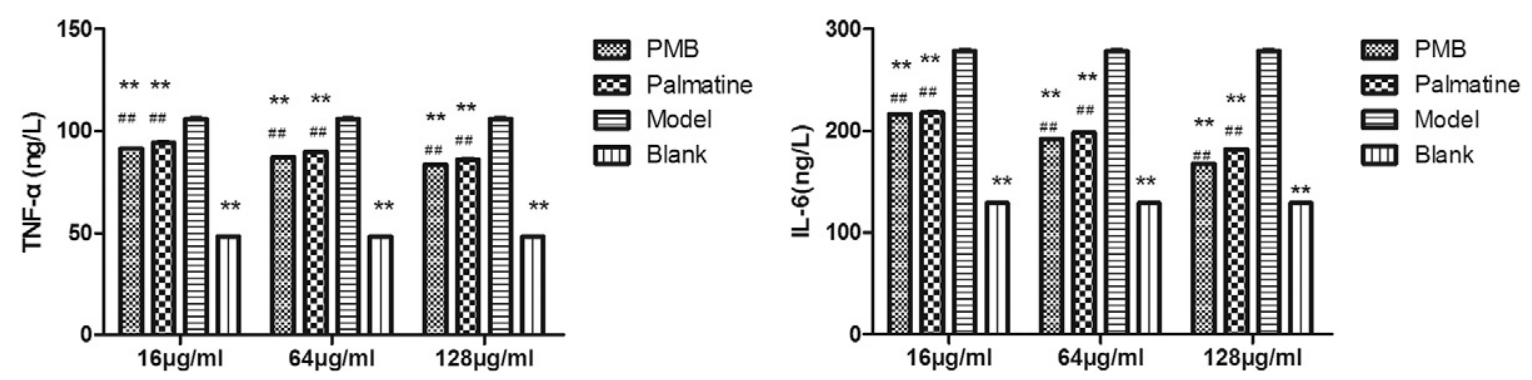

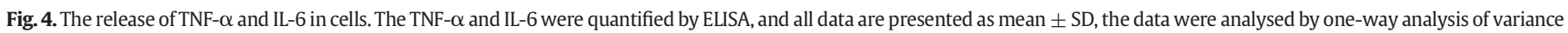
(ANOVA) followed by Dunnett's method. Compared with the model group, ${ }^{*} p<0.05,{ }^{* *} p<0.01$; Compared with the blank group, ${ }^{*} p<0.05$, ${ }^{\# \#} p<0.01$. 
Table 2

The protective activity of palmatine and PMB from LPS challenge.

\begin{tabular}{llllll}
\hline Group & $\mathrm{n}$ & $\begin{array}{l}\text { Dose } \\
(\mathrm{mg} / \mathrm{kg})\end{array}$ & $\begin{array}{l}\text { LPS } \\
(\mathrm{mg} / \mathrm{kg})\end{array}$ & $\begin{array}{l}\text { Deaths } \\
(\mathrm{n})\end{array}$ & $\begin{array}{l}\text { Survival rate } \\
(\%)\end{array}$ \\
\hline Model & 20 & 0 & 18 & 12 & 40 \\
Palmatine & 20 & 5 & 18 & 5 & $75^{*}$ \\
PMB & 20 & 1 & 18 & 4 & $80^{*}$
\end{tabular}

Compared with the model group, ${ }^{*} p<0.05$. In order to test the activity of protective organs in mice from lethal challenges with LPS, the test animals were injected with palmatine and PMB after lethal challenges with LPS ( $18 \mathrm{mg} / \mathrm{kg}$ ). The data were analysed by Chi-square tests.

$5 \% \mathrm{CO}_{2}$ at $37{ }^{\circ} \mathrm{C}$, until reaching $80 \%$ confluency. The medium was changed every 3 days.

\subsection{Measurement of IL-6 and TNF- $\alpha$ in cell}

Raw264.7 cells were seeded into 96-well tissue culture plates and cultured for $2 \mathrm{~h}$ in a humidified atmosphere of $5 \% \mathrm{CO}_{2}$ at $37^{\circ} \mathrm{C}$. The experimental groups were divided into model, palmatine, PMB and blank groups. The palmatine and PMB groups were treated with $100 \mathrm{ng} / \mathrm{mL}$ of LPS, and then the palmatine group was given palmaine and the PMB group was treated with PMB at various concentrations while the blank group was not treated with any reagent, and the cells were cultured for $14 \mathrm{~h}$. The model group was treated with $100 \mathrm{ng} / \mathrm{mL}$ of LPS and cultured for $14 \mathrm{~h}$. The cell supernatant was obtained to assess the levels of IL- 6 and TNF- $\alpha$. The inhibitory effects on TNF- $\alpha$ and IL- 6 production were measured with an enzyme-linked immunosorbent assay (ELISA) kit in the supernatant of collected cells. Samples were analysed according to the manufacturer's instruction.

\subsection{Real-time RT-PCR analysis of TLR4, IL-6 and TNF- $\alpha$ mRNA expression in cells}

Total RNA was obtained from RAW264.7 cells with the treatment of the Trizol reagent and Dnase was obtained after treatment of Turbo Dnase ${ }^{\circledR}$ (Ambion). RNA was reverse transcribed with the aid of the Superscript $^{\mathrm{TM}}$ first-strand cDNA synthesis kit. Primer sequences of sense and antisense primers for IL- 6 were $5^{\prime}$-CACCACCATCAAGGACTCAAAT$3^{\prime}$ and $5^{\prime}$-CAGGGAAGAATCTGGAAAGGT-3', for TNF- $\alpha$ were $5^{\prime}$ CTGGGAAATCGTGGAAATGAG-3' and 5'-GACTCTGGCTTTGTCTTTCTTGT TA-3', for TLR4 were 5'-TGGTTTACACGTCCATCGGT-3' and 5'-ATCAAT GGTCACATCACATAGTCC- $3^{\prime}$, and for $\beta$-actin were $5^{\prime}$-TGGTTTACACGT CCATCGGT- $3^{\prime}$ and $5^{\prime}$-ATCAATGGTCACATCACATAGTCC-3'. Thermal cycling conditions for the PCR reactions were $70{ }^{\circ} \mathrm{C}$ for 5 min followed by 40 cycles of $95^{\circ} \mathrm{C}$ for $3 \mathrm{~min}, 95^{\circ} \mathrm{C}$ for $15 \mathrm{~s}$, and $60{ }^{\circ} \mathrm{C}$ for $40 \mathrm{~s}$. The amplification of polymerase reaction products was performed with the aid of these primers. Polymerase reaction products were cloned into the pGEMT vector and sequenced for confirmation. Real-time reactions were carried out with the help of a real-time machine. The abundance of each gene was assessed through comparison to the standard curve. The values of IL- 6 and TNF- $\alpha$ were normalized to $\beta$-actin. Each sample was assessed three times.

\subsection{Animal experiments}

The animals needed for the experiments were housed at room temperature with a humidity of 55-60\%. On the basis of an equivalent dose of HJD, palmatine ( $5 \mathrm{mg} / \mathrm{kg}$ ) was injected through the tail vein for 2 consecutive days, and no mice died in the experiment. This experiment confirmed that compound palmatine was safe and nontoxic at its current dosages. To determine if palmatine could protect mice from the lethal toxicity of LPS, Balb/c mice (4-6 weeks weighing $20 \pm 2 \mathrm{~g}$ ) were divided into 3 groups: model, palmatine and PMB, with 20 in each group. All mice of the model, palmatine and PMB groups were administered with LPS $(18 \mathrm{mg} / \mathrm{kg})$, and then mice in the palmatine group received palmatine, and mice in the PMB group received PMB. In the continuous study, Balb/c mice were randomly divided into 4 groups (50 mice/group, 10 mice for each time point) and were intravenously injected as follows: LPS (18 $\mathrm{mg} / \mathrm{kg}$ ) in model group and LPS (18 $\mathrm{mg} / \mathrm{kg}$ ) plus palmatine $(5 \mathrm{mg} / \mathrm{kg}$ ) in palmatine group and LPS $(18 \mathrm{mg} / \mathrm{kg})$ plus PMB $(1 \mathrm{mg} / \mathrm{kg})$ in PMB group. The blank group, was injected with saline. The total injection volume was $0.2 \mathrm{~mL}$ per $20 \mathrm{~g}$ bodyweight. Special care was taken to minimize animal discomfort during all procedures by administering anaesthetics. At the end of the treatment, rats were sacrificed by cervical dislocation under general anaesthesia induced by pentobarbital. For animals that died during the study, pentobarbital was used to anesthetize before they died.

\subsection{LPS, IL-6 and TNF- $\alpha$ measurement in blood}

Blood samples $(0.5 \mathrm{~mL})$ were taken at $2,6,12,24$ and $48 \mathrm{~h}$ after the start of the experiment, and the serum was stored at $-20^{\circ} \mathrm{C}$ for subsequent LPS, TNF- $\alpha$ and IL- 6 assays. Meanwhile, $100 \mu \mathrm{L}$ of the plasma from groups 1-5 was diluted in $200 \mu \mathrm{L}$ of anticoagulants, and then the solution was incubated in $70{ }^{\circ} \mathrm{C}$ water for $10 \mathrm{~min}$ to inactivate heparin. The endotoxin (LPS) level in the solution was assayed with the treatment of the quantitative chromogenic tachypleus amebocyte lysate test.

qRT-PCR analysis of IL- 6 and TNF- $\alpha$ mRNA expression in liver and lung tissues.

Liver and lung tissues were obtained from the mice and crushed in liquid nitrogen. Total RNA was measured with the help of Trizol reagent, which is a one-step RNA isolation kit. The expressions levels of IL-6 and TNF- $\alpha$ mRNA were analysed following the protocols described above.

\subsection{Pathological investigation of the tissues}

The heart, liver, lung and kidney of mice were removed for pathological investigation, followed by treatment of formalin-fixed, paraffin-embedded, sliced and hematoxylin-eosin (HE) stained tissues. Slides were visualized by standard light microscopy.

\subsection{Statistical analysis}

Statistical analysis was carried out using SPSS 17.0 software. The data are expressed as the mean $\pm \mathrm{SD}$. The data were analysed by oneway analysis of variance (ANOVA) followed by Dunnett's method and Chi-square tests. A $p$-value of $<0.05$ was considered significant, and a value $<0.01$ was considered highly significant.

\section{Results}

\subsection{Characterization of compounds}

Seven compounds were obtained from the fractions of HJD, and the structures were characterized by ${ }^{1} \mathrm{H}$ NMR and ${ }^{13} \mathrm{C}$ NMR spectra. The

Table 3

The level of LPS in blood $(\mathrm{n}=10, \overline{\mathrm{x}} \pm \mathrm{s})$.

\begin{tabular}{llll}
\hline Time & $\begin{array}{l}\text { Model } \\
(\mathrm{EU} / \mathrm{mL})\end{array}$ & $\begin{array}{l}\text { Palmatine } \\
(\mathrm{EU} / \mathrm{mL})\end{array}$ & $\begin{array}{l}\mathrm{PMB} \\
(\mathrm{EU} / \mathrm{mL})\end{array}$ \\
\hline $48 \mathrm{~h}$ & $3.89 \pm 0.09$ & $2.10 \pm 0.09^{* *}$ & $1.06 \pm 0.13^{* *}$ \\
$24 \mathrm{~h}$ & $5.50 \pm 0.12$ & $4.85 \pm 0.06^{* *}$ & $2.70 \pm 0.09^{* *}$ \\
$12 \mathrm{~h}$ & $5.04 \pm 0.07$ & $4.15 \pm 0.20^{* *}$ & $3.47 \pm 0.32^{* *}$ \\
$6 \mathrm{~h}$ & $6.13 \pm 0.14$ & $5.10 \pm 0.15^{* *}$ & $3.98 \pm 0.10^{* *}$ \\
$2 \mathrm{~h}$ & $7.22 \pm 0.06$ & $5.71 \pm 0.06^{* *}$ & $4.65 \pm 0.07^{* *}$ \\
\hline
\end{tabular}

Compared with the model group, ${ }^{*} p<0.05,{ }^{* *} p<0.01$. Blood samples $(0.5 \mathrm{~mL})$ from Balb/c mice were taken at $2,6,12,24$ and $48 \mathrm{~h}$ after inception of the experiment, and the serum was stored at $-20{ }^{\circ} \mathrm{C}$ for subsequent LPS and TNF- $\alpha$ and IL- 6 assays. Additionally, $100 \mu \mathrm{L}$ of the plasma from groups $1-5$ were diluted in $200 \mu \mathrm{L}$ of anticoagulants, and then the solutions were incubated in $70{ }^{\circ} \mathrm{C}$ water for $10 \mathrm{~min}$ in order to inactivate heparin. The LPS levels in the solutions were assayed with the treatment of quantitative chromogenic tachypleus amebocyt lysati test. The data were analysed by one-way analysis of variance (ANOVA) followed by Dunnett's method. 

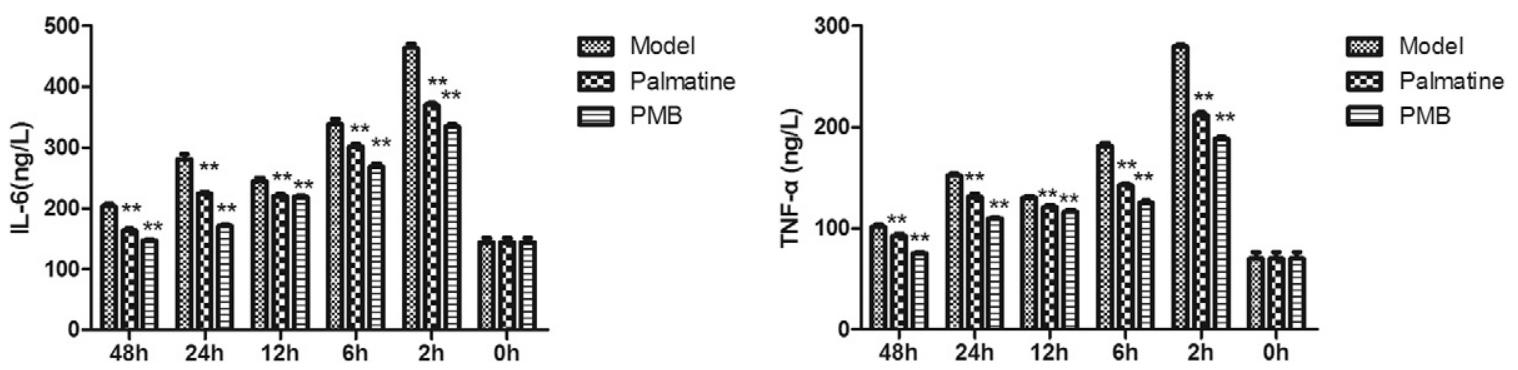

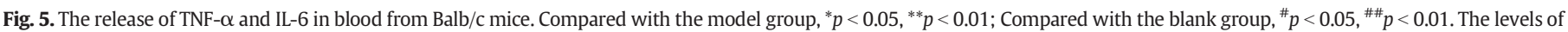
TNF- $\alpha$ and IL- 6 was determined at different time points and the data were analysed by one-way analysis of variance (ANOVA) followed by Dunnett's method.

compounds berberine, baicalin and geniposide were described as previously reported [32] (Fig. 1).

Compound 1 was obtained as a yellow needle crystal. By comparing the spectral data with that of the palmatine mentioned in the literature [33], the structure of compound 1 was determined to be $2,3,9,10$ tetramethoxy-5,6-dihydroisoquinolino[3,2-a] isoquinolinium.

${ }^{1} \mathrm{H} \mathrm{NMR}\left(\mathrm{CD}_{3} \mathrm{OD}\right): \delta 3.27(2 \mathrm{H}, \mathrm{t}, J=6.6 \mathrm{~Hz}), \delta 4.92(2 \mathrm{H}, \mathrm{t}, J=6.4 \mathrm{~Hz})$, $\delta 3.96(3 \mathrm{H}, \mathrm{s}), \delta 3.99(3 \mathrm{H}, \mathrm{s}), \delta 4.10(3 \mathrm{H}, \mathrm{s}), \delta 4.20(3 \mathrm{H}, \mathrm{s}), \delta 7.04(\mathrm{H}, \mathrm{s}), \delta$ $7.65(\mathrm{H}, \mathrm{s}), \delta 8.00(\mathrm{H}, \mathrm{d}, J=9.1 \mathrm{~Hz}), \delta 8.10(\mathrm{H}, \mathrm{d}, J=9.1 \mathrm{~Hz}), \delta 8.79(\mathrm{H}, \mathrm{s})$, $\delta 9.75(\mathrm{H}, \mathrm{s})$.

${ }^{13} \mathrm{C}$ NMR (CD $\left.{ }_{3} \mathrm{OD}\right): \delta 110.1, \delta 151.9, \delta 150.9, \delta 112.3, \delta 123.3, \delta 139.8$, $\delta 128.2, \delta 135.3, \delta 124.5, \delta 121.3, \delta 145.8, \delta 153.8, \delta 120.5, \delta 146.3, \delta 62.6$, $\delta 27.8, \delta 130.1, \delta 57.7, \delta 57.4, \delta 57.4, \delta 56.7$.

Compound 2 was obtained as an orange needle crystal. By comparing the spectral data with those of jatrorrhizine mentioned in the literature [34], the structure of compound 2 was determined to be 3-hydroxy2,9,10-trimethoxy-5,6-dihydroisoquino[3,2-a] isoquinolinium.
${ }^{1} \mathrm{H}$ NMR $\left(\left(\mathrm{CD}_{3} \mathrm{OD}\right)\right): \delta 3.19(2 \mathrm{H}, \mathrm{t}, J=6.4 \mathrm{~Hz}), \delta 4.89(2 \mathrm{H}, \mathrm{t}, J=$ $6.4 \mathrm{~Hz}), \delta 4.02(3 \mathrm{H}, \mathrm{s}), \delta 4.09(3 \mathrm{H}, \mathrm{s}), \delta 4.20(3 \mathrm{H}, \mathrm{s}), \delta 6.85(\mathrm{H}, \mathrm{s}), \delta$ $7.64(\mathrm{H}, \mathrm{s}), \delta 7.99(\mathrm{H}, \mathrm{d}, J=9.1 \mathrm{~Hz}), \delta 8.08(\mathrm{H}, \mathrm{d}, J=9.1 \mathrm{~Hz}), \delta 8.76$ $(\mathrm{H}, \mathrm{s}), \delta 9.72(\mathrm{H}, \mathrm{s})$.

${ }^{13} \mathrm{C}$ NMR (CD $\left.{ }_{3} \mathrm{OD}\right): \delta 110.1, \delta 151.7, \delta 149.7, \delta 115.9, \delta 123.2, \delta 140.3$, $\delta 128.2, \delta 135.5, \delta 124.4, \delta 120.9, \delta 145.7, \delta 151.9, \delta 119.4, \delta 146.1, \delta 62.5$, $\delta$ 27.7, $\delta$ 130.3, $\delta$ 57.7, $\delta$ 57.4, $\delta$ 57.0.

Compound 3 was obtained as a yellow powder. By comparing the spectral data with that of luteolin mentioned in the literature [35], the structure of compound 3 was determined to be 2-(3,4dihydroxyphenyl)-5,7-dihydroxy-4-benzopyrone.

${ }^{1} \mathrm{H}$ NMR (DMSO): $\delta 3.93(3 \mathrm{H}, \mathrm{m}), \delta 6.28(1 \mathrm{H}, \mathrm{s}), \delta 6.74(1 \mathrm{H}, \mathrm{s}), \delta 7.56$ $(3 \mathrm{H}, \mathrm{m}), \delta 8.00(2 \mathrm{H}, \mathrm{dd}, J=1.1,7.7 \mathrm{~Hz})$.

${ }^{13}$ C NMR (DMSO): $\delta 164.0, \delta 102.9, \delta 181.6, \delta 161.4, \delta 98.7, \delta 163.8, \delta$ 93.8, $\delta 157.2, \delta 103.7, \delta 121.5, \delta 113.3, \delta 145.6, \delta 149.5, \delta 115.9, \delta 118.9$.

Compound 4 was obtained as a yellow powder. By comparing the spectral data with that of wogonin mentioned in the literature [36],
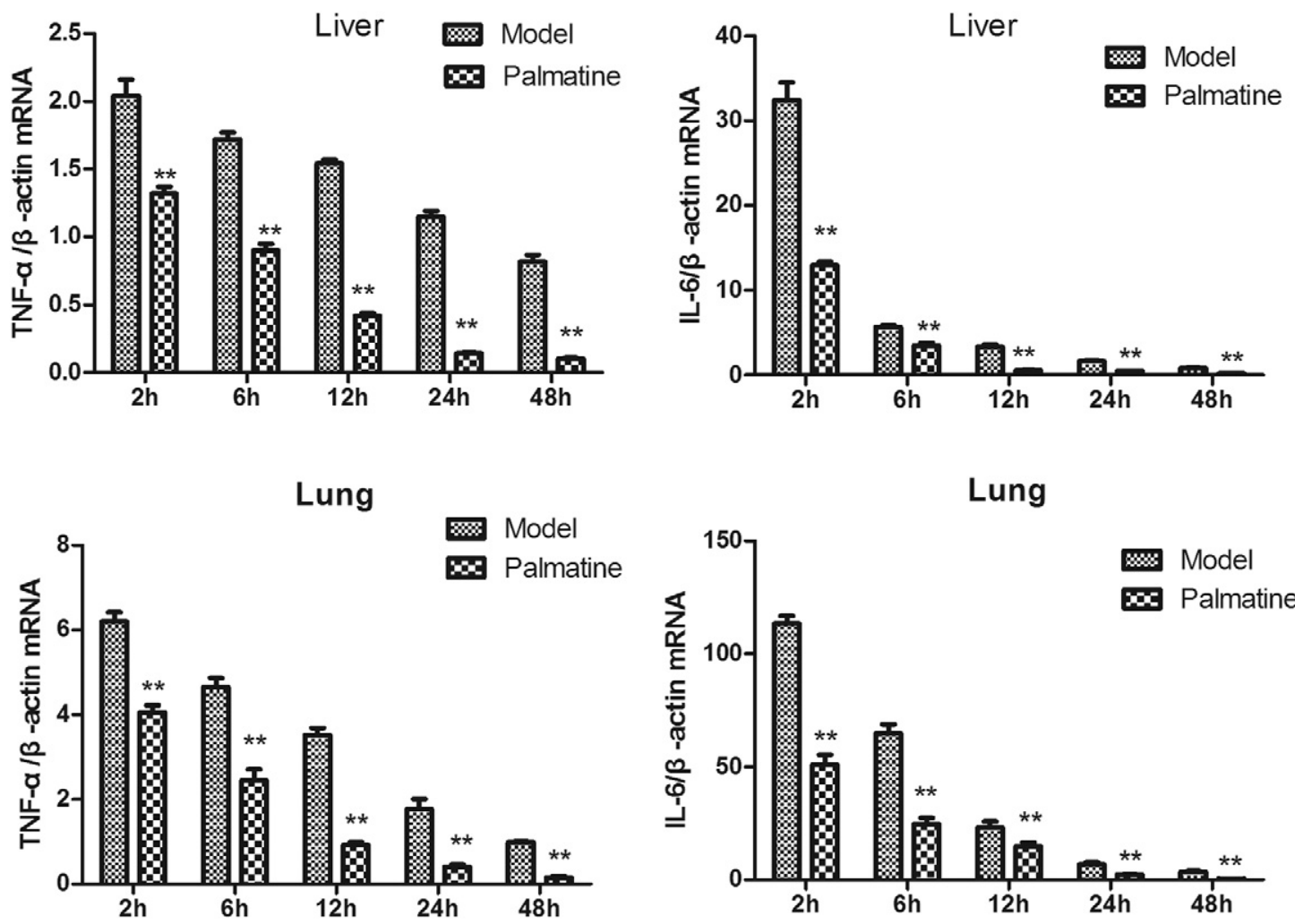

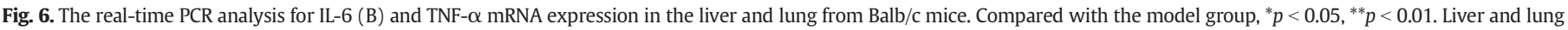

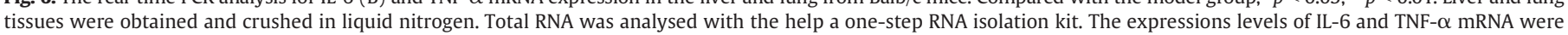
measured. The data were analysed by one-way analysis of variance (ANOVA) followed by Dunnett's method. 


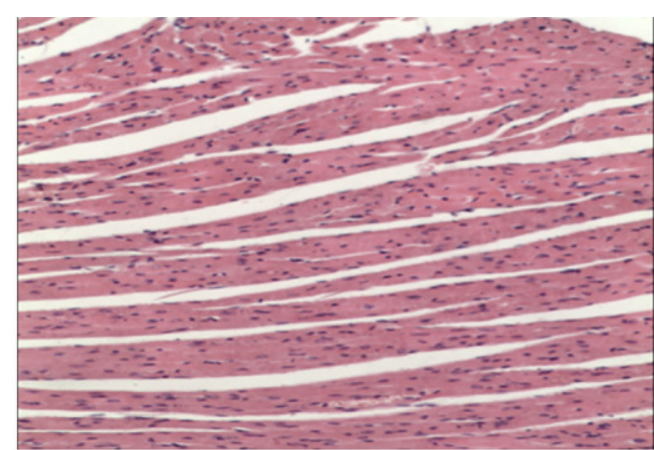

Blank group

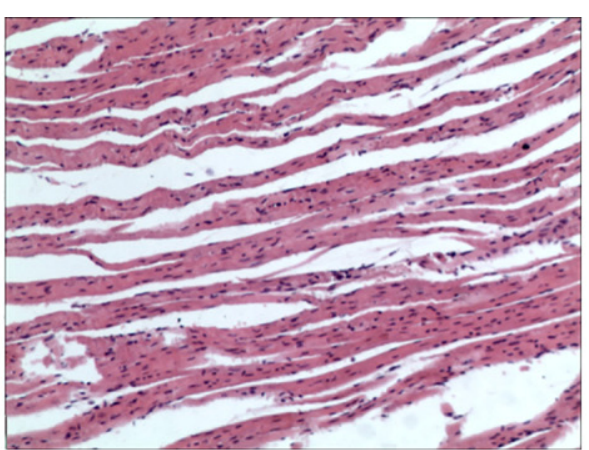

Model group

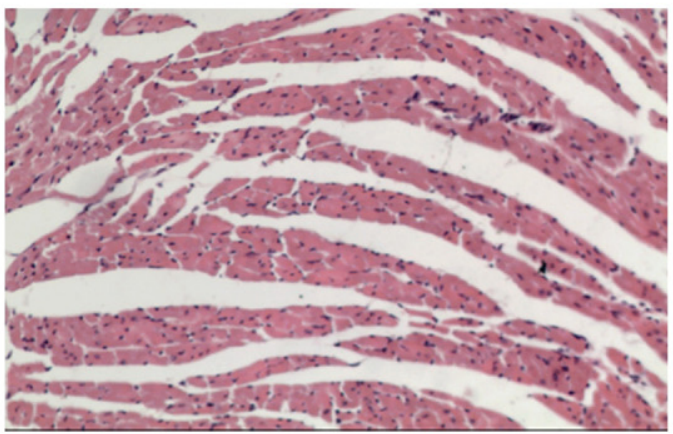

Palmatine group

(A)

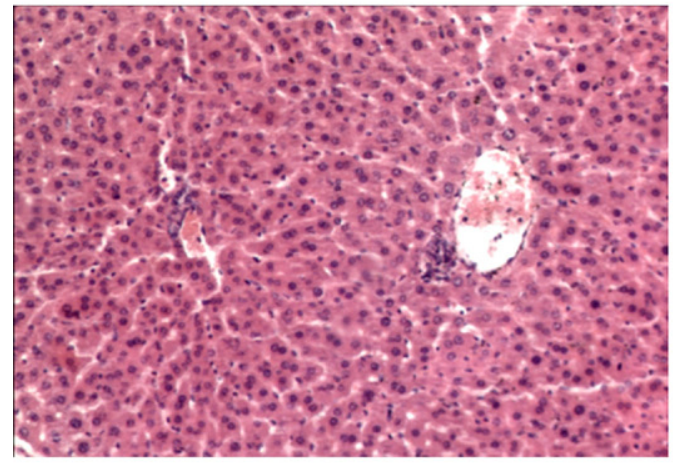

Blank group

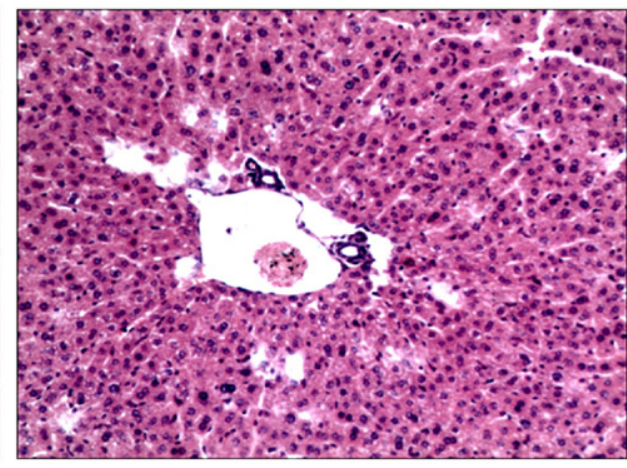

Model group

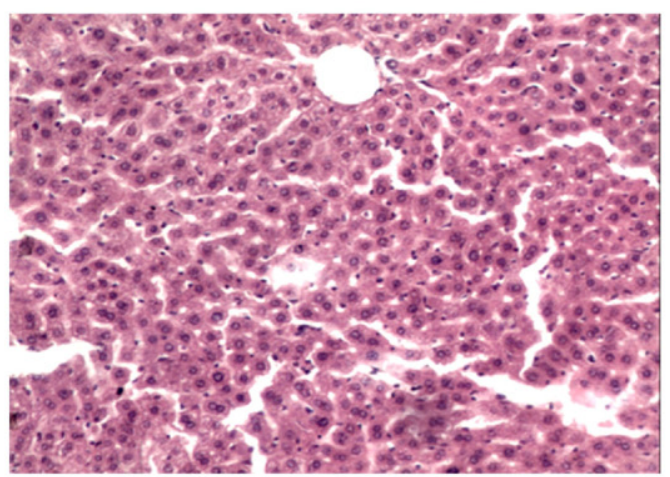

Palmatine group

(B)

Fig. 7. The liver, lung, heart, and kidney of the Balb/c mice were obtained $24 \mathrm{~h}$ after the start of the experiment. Pathological investigation was performed following the treatment of formalin-fixed, paraffin-embedded, and stained tissues. (A) The heart tissues of the mice. (B) The liver tissues of the mice. (C) The lung tissues of the mice. (D) The kidney tissues of the mice. 


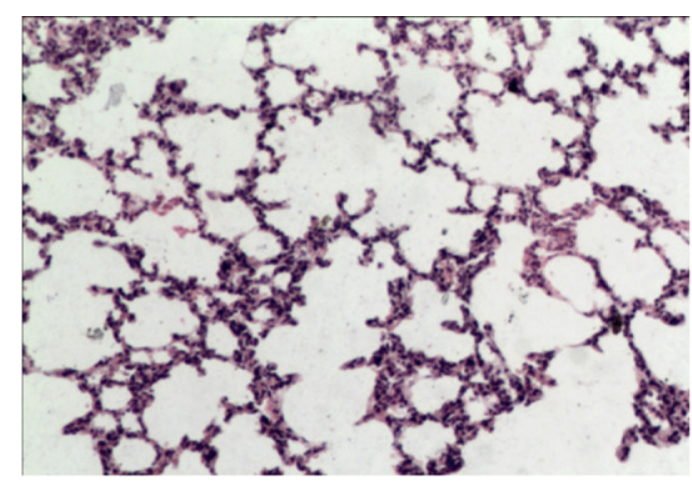

Blank group

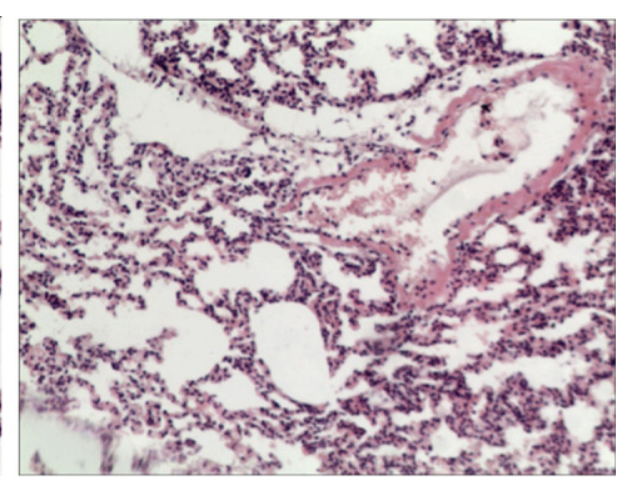

Model group

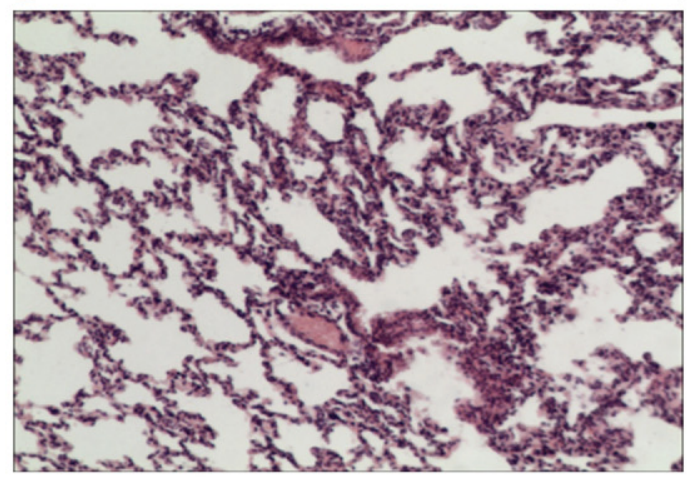

Palmatine group

(C)

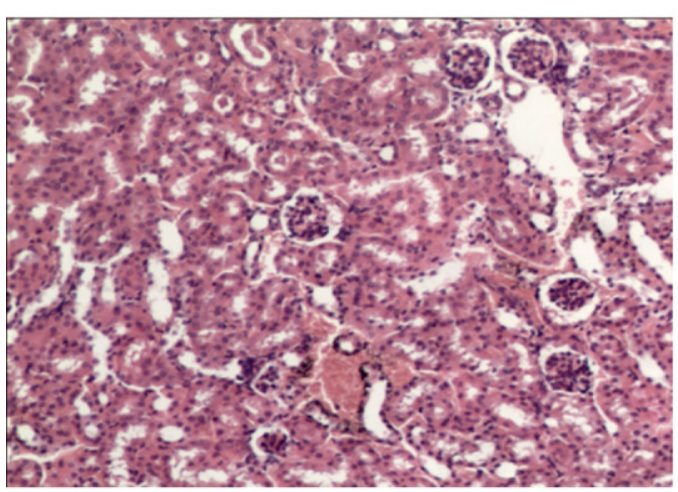

Blank group

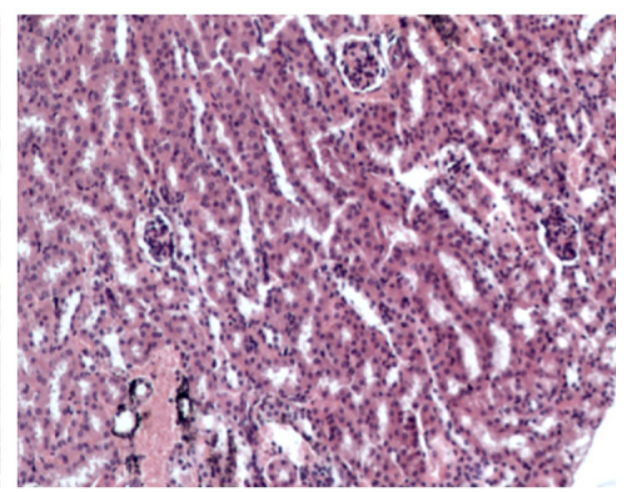

Model group

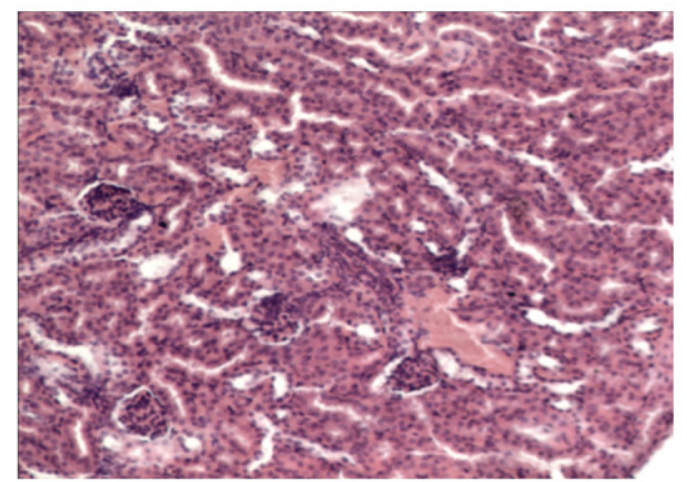

Palmatine group

(D)

Fig. 7 (continued). 
the structure of compound 4 was determined to be 5,7-dihydroxy-8methoxy-2-phenyl-4H-chromen-4-one.

${ }^{1} \mathrm{H}$ NMR ((CD $\left.\left.\mathrm{OD}\right)\right): \delta 3.93(3 \mathrm{H}, \mathrm{m}), \delta 6.28(1 \mathrm{H}, \mathrm{s}), \delta 6.74(1 \mathrm{H}, \mathrm{s}), \delta$ $7.54(3 \mathrm{H}, \mathrm{m}), \delta 8.00(2 \mathrm{H}, \mathrm{dd}, J=1.1,7.7 \mathrm{~Hz})$.

${ }^{13} \mathrm{C} \mathrm{NMR}\left(\mathrm{CD}_{3} \mathrm{OD}\right): \delta 165.4, \delta 106.0, \delta 184.0, \delta 158.3, \delta 100.5, \delta 159.1$, $\delta 129.4, \delta 151.4, \delta 105.5, \delta 132.6, \delta 127.4, \delta 130.3, \delta 133.1, \delta 130.3, \delta$ $127.4, \delta 62.01$.

\subsection{The affinity assay for lipid $A$}

To define the specificity of PMB for lipid A, the $K_{\mathrm{d}}$ value was measured by FASTfit. The affinity of the components for lipid A was compared to PMB, a compound with high affinity for lipid A. When PMB was pre-incubated with lipid A, lipid A was immobilized on the surface of a hydrophobic cuvette as described in the materials and methods section. Different concentrations of PMB were added to the immobilized lipid A, and the $K_{\mathrm{d}}$ value was measured. The $K_{\mathrm{d}}$ value of PMB was $11.1 \mathrm{nM}$. The affinity assays for each compound and lipid A were carried out as described in the methods above (Figs. 2-3). The $K_{\mathrm{d}}$ values of the compound palmatine was $29.7 \mathrm{nM}$.

\subsection{The experiment in vitro}

To determine the effects of IL- 6 and TNF- $\alpha$ release in LPS-stimulated Raw264.7 cells, the cells were treated with different concentrations of palmatine $(16,64$ and $128 \mu \mathrm{g} / \mathrm{mL})$ followed by stimulation with LPS (100 ng/mL) for $12 \mathrm{~h}$. In the model group, stimulation of cells with LPS resulted in significant enhancement of IL- 6 and TNF- $\alpha$ release in conditioned medium compared with the non-stimulated control cells in the control group. However, the study indicated that cells pre-treated with palmatine showed a dose-dependent reduction in IL- 6 and TNF- $\alpha$ release following stimulation with LPS. This indicates that palmatine has the potential to inhibit LPS-induced IL- 6 and TNF- $\alpha$ release in Raw264.7 cells (Fig. 4).

\section{4. $m R N A$ expression in RAW264.7}

Upon LPS stimulation, the cells from a broad spectrum of immune mediators such as cytokines that can lead to LPS-related disease states. To confirm that palmatine inhibits LPS signalling, real-time analysis was conducted. This study verified that palmatine could significantly inhibit the increasing expression of IL- 6 and TNF- $\alpha$ in the LPS-challenged RAW264.7 cells compared to the model group (Table 1).

\subsection{Protecting mice from LPS challenge}

To determine if palmatine could protect mice from lethal toxicity of LPS, test animals were injected with palmatine after lethal challenge with LPS (18 mg/kg). Approximately 20 mice were challenged by LPS, and only 8 survived (Table 2). Compared to the model group, animals treated with palmatine were protected from LPS-induced lethality.

\subsection{Neutralization of LPS in vivo}

As described above, neutralization of LPS was carried out with the aid of quantitative chromogenic tachypleus amebocyte lysate, allowing the detection of free LPS. The results indicated that the LPS level in plasma was highest $2 \mathrm{~h}$ after intravenous injection and recovered to a normal level after $48 \mathrm{~h}$ (Table 3 ). LPS levels of the palmatine group were lower than that of the model group $(P<0.01)$. Compared to the model group, the group treated with palmatine exhibited strong LPS neutralizing activity.

\subsection{The release of TNF- $\alpha$ and IL-6 in the blood}

The palmatine group activity was closely associated with TNF- $\alpha$ and IL-6 levels. Therefore, we tested the levels of TNF- $\alpha$ and IL- 6 in an endotoxic mouse model. In this experiment, the mice that were treated with LPS showed a large increase in TNF- $\alpha$ and IL- 6 , which peaked $2 \mathrm{~h}$ after LPS treatment. However, the peaks of TNF- $\alpha$ and IL- 6 were reduced after treatment with palmatine $(p<0.01)$ (Fig. 5).

\section{8. mRNA expression in liver and lung tissues}

The relative mRNA expression of IL- 6 and TNF- $\alpha$ in liver and lung tissues were calculated and compared to the model group. The expression levels in the palmatine treatment group were significantly lower than that of the model group $(P<0.01)$ (Fig. 6$)$. The study showed that palmatine could significantly inhibit the increasing expression of IL-6 and TNF- $\alpha$ induced by LPS in the LPS-challenged animal model compared to the model group.

\subsection{Pathological investigation}

Histological research of these organs indicated that organ injury appeared in the model animals. The results of H\&E staining verified that the model group exhibited significant inflammatory cell infiltration, swelling, congestion, incrassation, cell disorder, and morphological and structural changes in the organs. The treatment group showed protective activity and exhibited light inflammatory cell infiltration, regular arrangement in cells, mild oedema, relieved congestion, and normal morphology and structure. Palmatine displayed strong protective activity in the heart, liver, kidney and lung. The results are shown in Fig. 7. Unlike the model group, the treatment group exhibited protective activity in vital organs despite LPS-induced challenges.

\section{Discussion}

Despite many therapeutic improvements, sepsis still has high mortality rates, ranging from $22 \%$ to $56 \%$. Therefore, the treatment of sepsis has been a research hot spot for critical illnesses. LPS is regarded as the major mediator of sepsis, and research shows that the molecules that bind to and neutralize LPS could have potential anti-sepsis activity [21, 22]. Lipid $A$ is the active centre and toxic component of LPS. Therefore, lipid A is an ideal target for screening anti-sepsis agents [23,24]. PMB, an internationally recognized active compound with high affinity for lipid A, is a positively charged amphipathic cyclic oligopeptide linked to a single fatty acid that has exhibited stoichiometric (1:1) binding activity with lipid A and a $K_{\mathrm{d}}$ value of $10-100 \mathrm{nM}$ (as assessed by different methods) $[25,37]$. The affinity of PMB to lipid A was tested with the help of biosensor technology. The $K_{d}$ value (11.1) was elucidated with the aid of the FASTplot and FASTfit software used in this system. The $K_{\mathrm{d}}$ value indicated that the biosensor method for screening against the lipid A ligand was convenient, reliable and simple. Thus, the biosensor method was considered to be an effective platform for screening traditional Chinese medicine to treat sepsis. PMB was used as the control in the experiment to test the binding affinity of the compounds from HJD. Seven compounds, berberine, palmatine, jatrorrhizine, baicalin, luteolin, wogonin and gardenoside, were obtained from HJD and characterized via NMR. The affinity of the seven components measured from highest to lowest was palmatine, berberine, baicalin, geniposide, luteolin, jatrorrhizine and wogonin. Compounds palmatine, berberine and baicalin exhibited higher affinity to lipid A. Although palmatine and berberine are isoquinoline-type alkaloids and have similar structures, palmatine was used in the treatment groups due to its higher affinity to lipid A. Baicalin, a type of flavonoid, showed approximately the same affinity as berberine and was used as the treatment group for another study. However, palmatine displayed lower binding affinities to lipid A compared to PMB. Research indicated that most lipid $\mathrm{A}_{\mathrm{D}^{-}}$ 
GlcpN-containing backbones are phosphorylated at positions 1 of the proximal a-GlcpN (GlcpN I) and 4' of the distal b-GlcpN (GlcpN II) [38]. Based on structural analysis of the two compounds, we assumed that the positively charged quaternary ammonium of palmatine was bound to the negatively charged phosphoric acid of the disaccharide in lipid A [37]. The hydroxyl groups of baicalin can react with the phosphate groups in lipid A to form an ester [39]. Although the affinity between palmatine and baicalin to lipid A accounts for $20 \%$ and $10 \%$ of the affinity for PMB, respectively, both compounds exhibited affinity for lipid $\mathrm{A}$, which indicates that the two compounds function together as an anti-sepsis reagent in HJD. Therefore, given the high affinities for lipid A, palmatine was used for further in vitro and in vivo experiments.

The experiments were carried out in vitro and in vivo. Different concentrations of palmatine $(16,64$ and $128 \mu \mathrm{g} / \mathrm{mL})$ were used to treat Raw264.7 cells followed by stimulation with LPS $(100 \mathrm{ng} / \mathrm{mL})$ for $14 \mathrm{~h}$. The release and mRNA expression of IL- 6 and TNF- $\alpha$ were evaluated in LPS-stimulated Raw264.7 cells. The model group showed significant enhancement of IL- 6 and TNF- $\alpha$ release in conditioned medium compared to the control group. However, cells treated with palmatine exhibited a dose-dependent reduction in IL- 6 and TNF- $\alpha$ release following LPS-stimulation. These results indicated that palmatine could significantly inhibit the increasing expression of IL- 6 and TNF- $\alpha$ induced by LPS. The palmatine group showed similar activity as the group treated with PMB in inhibiting the release of IL- 6 and TNF- $\alpha$. This result verifies that palmatine could inhibit the release of IL- 6 and TNF- $\alpha$ and block LPS signalling in vitro.

Model animals were injected with palmatine for activity assays. Studies indicate that the core of sepsis is organ failure, and most sepsis patients are LPS-positive, indicating that sepsis has a high correlation with LPS levels. Therefore, the activity experiments were carried out to assess the pathology and levels of LPS, IL- 6 and TNF- $\alpha$ for 2-48 h. In these three treatment groups, palmatine neutralized LPS and reduced the release of inflammatory factors IL-6 and TNF- $\alpha(P<0.01)$. Palmatine showed similar activity to PMB and reduced the mortality significantly by neutralizing LPS in vivo. Palmatine exhibited anti-inflammatory activity by reducing the expression of the iNOS protein and then inhibiting the release of NO in LPS-induced RAW264.7 cells [40]. This result suggests that palmatine may inhibit inflammatory factors by neutralizing LPS and inhibiting the TLR4 pathway. Pathological research demonstrated that the model group exhibited different degrees of lesions on LS-induced organs, whereas the treatment groups exhibited varying protective activity on vital organs. The group treated with palmatine exhibited strong protective activity on the heart, lung, kidney, and liver. Palmatine is one of the main components of Coptis chinensis Franch and Cortex Phellodendri. Multiple components of HJD show the ability to neutralize LPS activity and reduce IL- 6 and TNF- $\alpha$ levels induced by LPS. Therefore, HJD is a valid treatment option to protect against LPS-induced multiple organ dysfunction syndrome. There is still mortality of patients who have suffered from septic shock despite rapid progress in developing antibiotics and other therapeutic methods in clinical practice [41]. With the advantage of lower cost, faster curative effect and few side effects, HJD could be widely utilized as a drug in the treatment of LPS-induced diseases including sepsis. It is essential to figure out the mechanism of HJD for the treatment of sepsis. Given that LPS infection is complex, there may exist many possible mechanisms of HJD for treating sepsis, which all need to be further investigated. Therefore, further studies on HJD are critical and may aid in the design of effective interventions for treating sepsis.

\section{Conclusion}

The results indicate that a biosensor can identify high affinity compounds between lipid A and PMB and could be used to separate and extract the effective components of TCM for anti-LPS/lipid A activity. The compound palmatine from HJD showed high affinity for lipid A and was used as the treatment group in the in vitro and in vivo studies. The results indicated that palmatine neutralized LPS by binding to lipid A and reduced the release of IL- 6 and TNF- $\alpha$ induced by LPS. Furthermore, palmatine exhibited protective activity in vital organs compared to the LPS-induced animal model. This result suggests that HJD is an ideal treatment for sepsis given that multiple HJD components have the ability to neutralize LPS, decrease the release of IL- 6 and TNF- $\alpha$ induced by LPS, and protect vital organs.

\section{Acknowledgments}

This project was supported by the National Natural Science Foundation of China (No. 81303205), the program for Liaoning General Research (L2015330), and the program for Liaoning Science and Technology (201601187 and 201202153). None of the authors declare any conflict of interest in this study. The authors are thankful to the Medical Research Center of the Third Military Medical University for assistance during the affinity testing.

\section{References}

[1] M. Antonio, H. Otto, D.L. Flaviana, C. Maire, N. Alessandra, D. Gerardino, et al., Chemistry of lipid A: at the heart of innate immunity, Chem. Eur. J. 21 (2015) 500-519.

[2] X.Y. Wang, P.J. Quinn, Lipopolysaccharide: biosynthetic pathway and structure modification, Prog. Lipid Res. 49 (2010) 97-107.

[3] C. Alexander, E.T. Rietschel, Bacterial lipopolysaccharides and innate immunity, J. Endotoxin Res. 7 (2001) 167-202.

[4] M.R. Leonardo, R.A. Silva, S. Assed, P. Nelson-Filho, Importance of bacterial endotoxin (LPS) in endodontics, J. Appl. Oral Sci. 12 (2004) 93-98.

[5] S.K. Panda, S. Kumar, N.C. Tupperwar, T. Vaidya, A. George, S. Rath, et al., Chitohexaose activates macrophages by alternate pathway through TLR4 and blocks endotoxemia, PLoS Pathog. 8 (2012), e1002717.

[6] M. Chu, R. Ding, Z.Y. Chu, M.B. Zhang, X.Y. Liu, S.H. Xie, et al., Role of berberine in anti-bacterial as a high-affinity LPS antagonist binding to TLR4/MD-2 receptor, BMC Complement. Altern. Med. 14 (2014) 89.

[7] S.G. Gattis, H.S. Chung, M.S. Trent, C.R. Raetz, The origin of 8-amino-3,8-dideoxy-Dmanno-octulosonic acid (Kdo8N) in the lipopolysaccharide of Shewanella oneidensis, J. Biol. Chem. 288 (2013) 9216-9225.

[8] T.D. Herath, R.P. Darveau, C.J. Seneviratne, C.Y. Wang, Y. Wang, L. Jin, Tetra-And penta-acylated lipid a structures of porphyromonas gingivalis LPS differentially activate TLR4-mediated NF- $\kappa$ B signal transduction cascade and immuno-inflammatory response in human gingival fibroblasts, PLoS One 8 (2013), e58496.

[9] S.P. Beom, H.S. Dong, M.K. Ho, C. Byong-Seok, H. Lee, J.O. Lee, The structural basis of lipopolysaccharide recognition by the TLR4-MD-2 complex, Nature 458 (2009) 1191-1196.

[10] K. Miyake, Roles for accessory molecules in microbial recognition by toll-like receptors, J. Endotoxin Res. 12 (2006) 195-204.

[11] F. Peri, M. Piazza, V. Calabrese, G. Damore, R. Cighetti, Exploring the LPS/TLR4 signal pathway with small molecules, Biochem. Soc. Trans. 38 (2010) 1390-1395.

[12] B. Beutler, Z. Jiang, P. Georgel, K. Crozat, B. Croker, S. Rutschmann, et al., Genetic analysis of host resistance: toll-like receptor signaling and immunity at large, Annu. Rev. Immunol. 24 (2006) 353-389.

[13] Y. Nagai, S. Akashi, M. Nagafuku, M. Ogata, Y. Iwakura, S. Akira, et al., Essential role of MD-2 in LPS responsiveness and TLR4 distribution, Nat. Immunol. 3 (2002) 667-672.

[14] R. Salomao, M.K. Brunialti, M.M. Rapozo, G.L. Baggio-Zappia, C. Galanos, M. Freudenberg, Bacterial sensing, cell signaling, and modulation of the immune response during sepsis, Shock 38 (2012) 227-242.

[15] B. Beutler, E.T. Rietschel, Innate immune sensing and its roots: the story of endotoxin, Nat. Rev. Immunol. 3 (2003) 169-176.

[16] M. Lacatus, Innate immunity in surgical patients, Chirurgia. (Bucur). 108 (2013) $18-25$.

[17] B. Gao, M.F. Tsan, Endotoxin contamination in recombinant human heat shock protein 70 (Hsp70) preparation is responsible for the induction of tumor necrosis factor alpha release by murine macrophages, J. Biol. Chem. 278 (2003) 174-179.

[18] K.D. Smith, E. Andersen-Nissen, F. Hayashi, K. Strobe, M.A. Beroman, S.L. Barrett, et al., Toll-like receptor 5 recognizes a conserved site on flagellin required for protofilament formation and bacterial motility, Nat. Immunol. 4 (2003) 1247-1253.

[19] O. Takeuchi, T. Kawai, P.F. Muhlradt, M. Morr, J.D. Radolf, A. Zychlinsky, et al., Discrimination of bacterial lipoproteins by toll-like receptor 6, Int. Immunol. 13 (2001) 933-940

[20] S.S. Diebold, T. Kaisho, H. Hemmi, S. Akira, C. Reis e Sousa, Innate antiviral responses by means of TLR7-mediated recognition of single-stranded RNA, Science 303 (2004) 1529-1531.

[21] A. Wiese, K. Brandenburg, A.J. Ulmer, U. Seydel, S. Müller-Loennies, The dual role of lipopolysaccharide as effector and target molecule, Biol. Chem. 380 (1999) 767-784.

[22] M.G. Vallespi, J.C. Alvarez-Obregon, I. Rodriguez-Alonso, T. Montero, H. Garay, 0. Reyes, et al., A Limulus anti-LPS factor-derived peptide modulates cytokine gene expression and promotes resolution of bacterial acute infection in mice, Int. Immunopharmacol. 3 (2003) 247-256. 
[23] T.J. Wyckoff, C.R. Raetz, J.E. Jackman, Antibacterial and anti-inflammatory agents that target endotoxin, Trends Microbiol. 6 (1998) 154-159.

[24] Y.N. Wong, D. Rossignol, J.R. Rose, U. Seydel, S. Müller-Loennies, Safety, pharmacokinetics, and pharmacodynamics of E5564, a lipid A antagonist, during an ascending single-dose clinical study, J. Clin. Pharmacol. 43 (2003) 735-742.

[25] C. Ried, B. Wahl, T. Miethke, G. Wellnhofer, C. Landgraf, J. Schneider-Mergener, et al., High affinity endotoxin-binding and neutralizing peptides based on the crystal structure of recombinant Limulus anti-lipopolysaccharide factor, J. Biol. Chem. 271 (1996) 28120-28127.

[26] L.M. Wang, X.Q. Yu, Advances of sepsis by Chinese medicine, Clin. J. Chin. Med. 25 (2013) 821-823 (In Chinese).

[27] X.J. Zhang, Y.X. Deng, Q.Z. Shi, M.Y. He, B. Chen, X.M. Qiu, Hypolipidemic effect of the Chinese polyherbal Huanglian Jiedu decoction in type 2 diabetic rats and its possible mechanism, Phytomedicine 21 (2014) 615-623.

[28] Y.L. Ma, T. Li, B.B. Wang, B. Jia, B. Chen, J. Su, et al., Protection of Huanglian Jiedu decoction on livers of hyperlipidemia mice, Zhongguo Zhong Xi Yi Jie He Za Zhi 33 (2013) 1107-1111 (In Chinese).

[29] Y.B. Feng, W.Q. Luo, S.Q. Zhu, Explore new clinical application of Huanglian and corresponding compound prescriptions from their traditional use, Zhongguo Zhong Yao Za Zhi. 33 (2008) 1221-1225 (In Chinese).

[30] C.L. Xiao, H.Y. Huang, Clinical study on sepsis with the method of detoxification, Guide of China Medicine, 10, 2009, pp. 226-227 (In Chinese).

[31] X. Huang, L.H. Guo, S.Y. Ma, M.Z. Zhang, L. Wang, Protective effects of Huanglian Jiedu decoction on cardiac state in rats with sepsis, Chin. J. Integ. Med. Cardio-/ Cerebrovasc. Dis. 10 (2012) 710-712 (In Chinese).

[32] G.R. Chen, G. Zhang, M.Y. Li, J. Jing, J. Wang, X. Zhang, B. Mackie, D.Q. Dou, The effective components of Huanglian Jiedu decoction against sepsis evaluated by a lipid Abased affinity biosensor, J. Ethnopharmacol. 186 (2016) 369-376.
[33] H.B. Li, J. Hu, J.C. Chen, M.H. Qiu, Chemical constituents of Tinospora Craveniana, Nat Prod. Res. Dev. 17 (2005) 125-127 (In Chinese).

[34] C.M. Cheng, Y. Dai, X.Z. Huang, Y. Zhu, J.H. Dai, X.F. Liu, et al., Chemical constituents from roots of Tinospora sagittata var. Yunnanensis, Chin. Tradit. Herb. Drug 41 (2010) 689-692 (In Chinese).

[35] S.H. Li, A.M. Li, X.J. Wu, Chemical constituents in Sambucus chinensis, Chin. Tradit. Herb. Drug 42 (2011) 1502-1504 (In Chinese).

[36] A.H. Song, W. Li, X.Y. Sun, J. Fan, L.J. Wu, Studies on chemical constituents of the roots of Scutellaria viscidula, Bge, 20, 2003 339-341.

[37] S.A. David, K.A. Balasubramanian, V.I. Mathan, P. Balaram, Analysis of the binding of PMB to endotoxic lipid A and core glycolipid using a fluorescent displacement probe, Biochim. Biophys. Acta 1165 (1992) 147-152.

[38] A. Molinaro, O. Holst, F. Di Lorenzo, M. Callaghan, A. Nurisso, G. D'Errico, et al. Chemistry of lipid A: at the heart of innate immunity, Chemistry 21 (2015) 500-519.

[39] M.S. Trent, C.M. Stead, A.X. Tran, J.V. Hankins, Diversity of endotoxin and its impact on pathogenesis, J. Endotoxin Res. 12 (2006) 205-223.

[40] J. Yang, H.D. Wang, D.X. Lu, M.A. Yan, F.B. Zhang, R.X. Liang, et al., Effects of neutral sulfate berberine on LPS-reduced cardiomyocyte TNF-alpha secretion abnormalcalcium cycling, and cardiac dysfunction, Acta Pharmacol. Sin. 27 (2006) $173-178$.

[41] U. Ohto, K. Fukase, K. Miyake, T. Shimizu, Structural basis of species-specific endotoxin sensing by innate immune receptor TLR4/D-2, Proc. Natl. Acad. Sci. U. S. A. 109 (2012) 7421-7426. 